\title{
THE POLITICAL CONTESTATION OF NORD STREAM PROJECT: MULTIDIMENSIONAL ANALYSIS
}

\author{
Ihor Moshenets \\ Postgraduate Student, National Institute of Strategic Studies, Ukraine \\ e-mail: i.moshenets@gmail.com,orcid.org/0000-0002-0315-510X
}

\section{Summary}

This article aims to explain the influence of different dimensions of political deliberation over the two strings of the Nord Stream pipeline on the European Union's ability to act as a unified actor with coherent strategy in the realm of global energy diplomacy. This study concentrated on four main cleavages of the project's political contestation: international, supranational, transatlantic and environmental. The analysis of the Nord Stream project's political contestation implies four basic insights. The first one is the absence of principal unity among EU member states regarding both of their economic interests and interpretation of key political developments on the continent. Second, the market-oriented spirit of EU legislation complicated the incorporation of any broader geopolitical considerations in decision-making over the pipeline's future. Third, the EU's overdependence on the US in geostrategic issues highlighted problems in realization of idea of "geopolitical Europe" as an independent actor with a coherent strategy on the international level. Fourth, the policies for reaching each of the three broad goals of EU energy policies (marketization, securitization and decarbonization) are often contradictory between each other, which was exemplified by the presented case.

Keywords: Nord Stream, natural gas trading, energy diplomacy, geopolitics, EU, US, Russian Federation.

DOI: https://doi.org/10.23856/4524

\section{Introduction}

The issue of pipeline Nord Stream in recent years turned to be one of the most heatedly discussed topics in international relations on the European continent.

This article aims to explain the influence of different dimensions of political deliberation over the two strings of the Nord Stream pipeline on the European Union's ability to act as a unified actor with coherent strategy in a realm of global energy diplomacy. The interest of competing sides and their strategies chosen for achieving desired policy goals would be especially taken into account.

Under the Nord Stream project we would broadly understand all four gas transporting pipelines linking Russia with northern Germany which were already built or are currently under construction by subsidiaries of Russian state-owned corporation Gazprom. The first two lines of the project, constructed at the beginning of 2010s were called in the media Nord Stream pipeline, and the last two lines being under construction from 2018 onwards - Nord Stream 2. In order to avoid the confusion in terms and to underline the continuity of the main political idea staying behind the construction of both strings, we would name all four lines in general Nord Stream project, and the first string - Nord Stream pipeline.

The Nord Stream project was researched by such scholars as S. Andersen, B. Gens, M. Honchar, O. Kravchenko, D. Langlet, P. Nöel, A. Riley, A. Schmidt-Felzmann, 
N. Sitter, M. Siddi, A. Strygul, O. Sukhodolia, K Talus, F. Umbach, A. Vihma and many others. Nevertheless, most of the existing studies highlight often some particular aspect of the Nord Stream project neglecting the multidimensional essence of the issue. It represents the main drawback of existing scholarship. For that reason, this study would try to explain the complex interrelation between the main dimensions of the conflict over the Nord Stream project.

This article would be structured as follows. The first section would be briefly dedicated to the history of the evolution of the Nord Stream pipeline project from the 1990s until the current time with paying attention to its broader political significance. The next four sections would be concentrated on four main cleavages of the project's political contestation: international, supranational, transatlantic and environment. The conclusion would be made at the end.

\section{The evolution and the role of the Nord Stream project}

The idea of constructing a pipeline from Russia to the northern part of Germany on the bottom of the Baltic Sea could be dated back to the 90s when Gazprom in partnership with company Neste from Finland created the joint company "North Transgas OY" which existed until 2006. However, the real progress started only from the middle of the decade. The new joint company was formed in 2005 in Swiss city Zug under the name North European Gas Pipeline Company (later renamed Nord Stream AG). The list of shareholders, apart from Gazprom, included German companies Wintershall (a subsidiary of BASF) and E.ON Ruhrgas. They were later supplemented with Dutch Nederlandse Gasunie in 2007 and French GDF Suez (since 2015 - Engie) in 2010 which bought part of the shares of German companies. A the end the shares were distributed as follows: Gazprom $-51 \%$, Wintershall and E.ON $-15.5 \%$ each, Gasunie and GDF Suez - 9\% each. The building of the first two lines of the Nordstream with an overall annual capacity of $55 \mathrm{bcm}$ was completed in 2010-2012.

Almost immediately after the successful construction of the pipeline Gazprom started to study the possibilities of doubling its capacity. The deterioration of relations between Russia and Ukraine in 2014 after the Russian occupation of Ukrainian Crimea and military support of pro-Russian separatists in the eastern part of the country created the need for Kremlin to reroute the transit of its natural gas export away from Ukraine until the expiration of the 2009 transition contract at the end of 2019. In September 2015 Gazprom together with BASF, Engie, E.ON, OMV and Shell decided to build the pipeline Nord Stream 2 repeating the route of the Nord Stream with exact capacity. For that reason they formed the joint company New European Pipeleine AG (later - Nord Stream 2 AG). However, after the threat of possible sanctions from Polish antimonopolist authority, Western European companies formally quited the project and Nord Stream-2 AG become fully owned by Gazprom. Nevertheless, the partners found alternative way of participating in the project as investors: in 2017 the agreement about the financing of construction work was signed between Nord Stream $2 \mathrm{AG}$ and Engie, OMV, Shell, Uniper, Wintershall (BASF subsidiary). Installing the pipes on the seabed began in July 2018 and was initially planned to end in 2019. Due to the delays with obtaining Danish environmental permits and US sanctions construction works were considerably prolonged. Nevertheless, it is expected to be completed in autumn 2021.

Nord Stream project is also supported by two onshore pipelines that span from the German shore of the Baltic sea toward the German-Czech border. The first of them, OPAL with an annual capacity of $36 \mathrm{bcm}$, was built in 2010-2011. Second, EUGAL with a capacity of $55 \mathrm{bcm}$ has been built since mid-2018 and started its operation in April 2021. 
Nord Stream project with its overall capacity of $110 \mathrm{bcm}$ per annum provides the ability for both Russia to bypass or substantially minimize the deliveries through traditional transit routes of Ukraine (146 bcm of annual gas transporting capacity), Belarus and Poland (33 bcm). In the view of project's initiators, its rationale is in limiting the possible negative influence of political conflicts between Russia and transiting countries on the security of gas supply.

The critics usually point to three main controversial aspects of the Nord Stream 2 project. First, it breaches so called principle of "EU energy solidarity". The trade with one group of EU countries might allow Russia to continue blackmailing its transit partners and importing countries with gas issues by minimizing dependency on their gas transporting systems from the Russian side. Second, this pipeline was claimed to be contradictory with officially proclaimed policy goals of enhancing the overall level of gas supply security in Europe, insomuch as it provides diversification of importing routes without diversification of importing sources. Third, many analytical studies have refuted the basic arguments of pipeline proponents by arguing that Nord Stream 2 project has little economic sense. Most remarkable from them are report prepared by two Russian analysts from state owned Sberbank where they concluded that the biggest beneficiaries from Nord Stream would be neither exporting side nor importing but the firms involved in construction works (Brzozowski, 2018).

\section{National cleavage of political contestation.}

The question of the Nord Stream project appeared as highly controversial established itself as an apple of discord for policy debates between the different EU member states. One part of the EU member states viewed the increase of economic interdependency with Russia provided by the Nord Stream project as an opportunity, other labeled it strictly as vulnerability due to their spatial localization in traditional "sphere of Russian influence".

To the most pronounced proponents of the second string of Nord Stream project belonged Germany, Netherlands, Austria, Belgium and Bulgaria, to the opponents - Poland, Lithuania, Latvia, Estonia, Romania. Other countries remained rather neutral towards the project or had changed their position depending on circumstances, like Italy or Hungary. Scandinavian EU members were prepared to grant all the needed permits for the project but were expecting the reaching of broad political compromise about the project satisfying all sides.

Each state has its own motivations which defined its position toward the project. Germany had an economic rationale for supporting the project. The country's bold approach for decarbonizing its economy and steady removal of goal from its energy mix (so-called "Energiewende") coupled with strong anti-nuclear sentiment paved the way for increased demand for natural gas. Due to the influence of unstable weather conditions for the production of renewable wind and solar electricity, gas was presented as the solution for ensuring the stable flow of electricity in the grid system during all times of the day. The decline of output of Dutch Groningen natural gas field, the biggest gas field on the territory of EU, created the need for additional gas supplies in the region of North-Western Europe (Wehrmann \& Wettengel, 2018).

Netherlands and Austria were in general favorable for the Nord Stream project. The main role played that the company with the headquarters on their territory participated in the project Dutch Gasunie as a shareholder in Nord Stream AG and Austrian OMV as one of the financers of Nord Stream 2. Bulgaria supported Nord Stream 2 project because of its general warm relations with Moscow and hoped to play a more important role in Balkan gas trading. After the deterioration of Russian-Turkish relations after the shooting down of a Russian military plane 
crossing the Turkish border in 2016, Bulgaria hoped to regain its role as a first destination point for the Russian subsea pipeline, as it was planned before 2015 (Gotev, 2019a).

The motivations of Poland's radical opposition to Nord Stream 2 construction are tightly connected to its interpretation of historical experience and previous economic dependency on Russian gas import. Transit revenues from the pipeline Yamal-Europe ( $33 \mathrm{bcm}$ per annum) were an important source of Polish budgetary income. Having developed a wider regional diplomatic strategy, Poland established itself also as an advocate of Ukrainian interest in this issue in the EU institutions. Baltic countries were traditionally against the increase of Russian economic influence in Europe due to their historical experience with Soviet occupation and their status as NATO borderland to Russia. Romania was another country affected by Russian bypassing pipelines anticipating losing of its transit status after the starting of Turkish Stream's operation.

Apart from described in other section political struggle on the platform of European Council, the anti-pipeline states managed to implement measures for influencing the process of object's construction: proposing alternative to the Nord Stream 2 pipeline roots (Amber pipeline advocated by Poland and Baltic countries at the beginning of 2010s); bulding new gas insfrastructure with co-financing from EU funds to minimize own dependency on Russia (LNG terminals in Polish Swinoujscie and Lithuanian Klaipeda; Gas Interconnector between Poland and Lithiania (GIPL), Baltic pipe between Danemark and Poland; Balticconnector between Estonia and Finland) (Vicari, 2019:11-15); complicating Gazprom's pipeline construction by legal means ( 6.45 billion euro fine issued for the participating in Nord Stream 2 construction companies by the Polish competition watchtdog in 2020 (EURACTIV, 2020)).

\section{Supranational cleavage of political contestation}

The second cleavage is a traditional division between the supranational EU institutions and national governments. The discussions over the Nord Stream project were, in this regard, the battleground between European Commission's policy entrepreneurship for closing the important gap in EU energy acquis and ending Gazprom's monopolist control over the Nord Stream, and resistance of particular countries defending the interests of their large companies exploiting this legal gap in their cooperation with Russians.

The position on the Nord Stream project has steadily evolved in Brussels. In 2006 Nord Stream obtained the status of the project of common interests. Members of the European Commission were present at both the official starting of the Nord Stream's construction works in April 2010, as well as on the formal ceremony of the pipeline's inauguration in November 2011.

In 2015 Gazprom's intention to double the existed capacities sparked much heated political debate. The question was discussed at the summit of the EU Council in December 2015 (Gotev, 2015). In February 2016 was published the open letter to the European Commission signed by the leaders of eight EU member states: Czech Republic, Estonia, Hungary, Latvia, Lithuania, Poland, Romania, Slovakia. They highlighted the possible negative impact of the proposed pipeline on the security situation in Central and Eastern Europe (Sytas, 2016). In his answer the President of the European Commission Jean-Claude Juncker assured them that Nord Stream 2 must fully comply with the norms of EU acquis, especially third energy package (European Political Strategy Center, 2017: 8).

From 2017 was clear that European Commission did not view the strategic rationale for a common EU energy security in extending the Nord Stream pipeline. The thinking of the European Commission on the Nord Stream 2 could be illustrated by the unofficial report prepared by the Commission's staff in 2017. It maintained that, in case of its successful construction, Nord 
Stream 2 would be hardly compatible with EU strategic goals (European Political Strategy Center, 2017: 1,2,6).

The main emphasis of the further discussion about the Nord Stream 2 was centered on the question, whether EU energy legislation should be applied to this project. The first view supported the claim of project owners that Nord Stream 2 should be exempted from the requirements of EU energy law similar to other pipelines connecting the EU territory from the third countries (Lissek, 2016). Another vision provided the inclusion in EU law jurisdiction of that part of the pipeline which was located in the maritime exclusive economic zone of Germany. Due to the practical hurdles in the legal division of one pipeline into two parts with different regimes of legal regulation, the proliferation of EU acquis' jurisdiction over the one part of Nord Stream might lead to the complete inclusion of the infrastructure object in the EU legal space (Riley, 2016). Russia was traditionally reluctant to implement EU energy law because its requirements of unbundling and third-party access were incompatible with the vertically-integrated structure of Gazprom which secured its revenues by controlling both extraction, transportation and marketing of natural gas. Therefore, it was highly possible that Gazprom may cancel the project in the case when the EU legal jurisdiction would be proliferated over the Nord Stream 2.

During 2016-2019, European Commission has pursued three different strategies in order to secure the compliance of Nord Stream 2 with the third energy package.

The first effort was in direct demand of compliance in order to avoid the Nord Stream 2 operation in the "legal void". But in 2017 the legal Service of the Commission and German national regulator both issued a negative judicial assessment of this proposal evaluating it as contradicting to the existed at that time norms of adopted in 2009 third gas directive. Another mechanism was the conclusion of a separate intergovernmental agreement between Russia and affected by the construction countries under the coordination of European Commission (Gotev, 2017). But this idea was also rejected by the legal service of European Council in September 2017. (de Jong \& Van de Graaf, 2020: 6-7).

After facing these obstacles, officials of the European Commission decided to change the legal base. In November 2017 Commission published the draft proposal for directive amendments which provided the inclusion of offshore pipelines going from the third countries to the EU territory into the jurisdiction of EU energy law. From November 2017 to April 2018 the work on the proposal was held in the Industry, Research and Energy Committee of EU parliament.

However, the process was substantially protracted after being sent to European Council. Three groups were clearly formed based on their position regarding the spreading of EU energy acquis over the Nord Stream. The first group included supporters of this decision including Estonia, Latvia, Lithuania, Poland and Romania. The group of opponents was formed by Germany, Netherlands, Belgium, Austria and Bulgaria. Most other countries were merely neutral to the issue. In order to obtain the blocking majority in the council, the opponents of the directive amendments needed to secure the votes of the four countries which comprised $35 \%$ of the EU population. However, the weight of the combined population of beforementioned group of countries represented only $27 \%$ of the total EU citizens.

This stalemate increased the weight of France in blocking or pushing for the decision. Paris, despite the presence of French company Engie among the beneficiaries of Nord Stream 2, has abstained from active participation in discussions over the gas directive amendments during most time of the process. But in February 2019 France surprisingly decided to support the last version of amendments, which made its adoption highly possible. French insistence on the 
Nord Stream 2 compliance with third energy package might play the role of bargaining chip for guaranteeing German concessions in other unrelated policy fields, as in French-German bargainings about the common Eurozone budget and debt system (Gotev, 2019b).

The final deal reached by the parties appeared as a compromise: Germany acceded to vote for the third directive amendments, but the final say on the project certification was agreed to be transferred on the national level (to Bundesnetzagentur) which kept Germans calm about the future of the pipeline (Simon, 2019). The amendments to the directive were adopted in April 2019. After that the members of the European Commission publicly recognized that the future of the project depends solely on Germans (EURACTIV, 2021).

However, despite eliminating the possibility for cancelling the project, directive amendments presupposed norms creating complications for Gazprom, which were followed by the German national energy regulator. In May 2020 Bundesnetzagentur refused to grant for Nord Stream-2 derogation (exception) from the EU rules, which presupposed that all norms of European energy legislation, such as third-party access, unbundling and commercial transparency should be implemented in regard to the offshore part of the pipeline, located no longer than 12 nautical miles from the seashore (Talus, 2020). The details of practical implementation of this requirement could be evaluated only after the beginning of the functioning of Nord Stream 2 and after the end of inititated by Gazprom court procedings aimed at annuling gas directive amendments (in EU Court of Justice and under Energy Charter Treaty).

\section{Transatlantic cleavage of political contestation}

The issue of the strategic autonomy of the EU as a unified actor with coherent strategy in foreign relations is a recurring question permanently arising regarding different events. The sanctions of Donald Trump's presidential administration against companies involved in the construction of the Nord Stream-2 pipeline showed the scope of US economic leverage over the EU. Also, these extraterritorial sanctions underlined the internal contradictions inside the EU. US actions converged with the interests of some EU member-states, like Poland or Baltic countries, to a larger extent than the activities of their western EU neighbors.

We can broadly define two possible motivations for US active involvement in the issues related to the Nord Stream project. The first one was in strategic support of Eastern and Central European countries against possible Russian economic pressure. American officials blamed Kremlin for the weaponization of the gas trade and therefore were presenting the US as acting on behalf of disadvantaged by Russian pipeline diplomacy countries, especially Ukraine (Janjevic, 2019). Such American position was met with enthusiasm by regional stakeholders, including Polish and Ukrainian officials (Rau \& Kuleba, 2021).

Second, Russian political elites and opponents of US sanctions against Nord Stream 2 underlined the presence of economic rationale for the US to block the pipeline. They framed active US diplomatic posture regarding this issue as American efforts to remove the pipeline as a possible competitor for the US LNG export in North-Western Europe. From the first day of its tenure, the presidential administration of Donald Trump advocated so-called "new energy realism" which presupposed the active promotion by the United States of its LNG export abroad. President Trump led very active energy diplomacy in the European region urging EU leaders to increase the levels of LNG purchases from the US (Vicari, 2019: 2-5).

Before May 2021, the US already imposed three rounds of sanctions on the project. They provided restrictions of obtaining US visa and the possibility of freezing the assets of companies located on the territory of the USA. The only way to avoid them was to quit voluntarily the 
project. The exact list of commercial entities subject to potential sanctions needed to be defined in detail by officials of the State Department. There were obliged to contact targeted companies to warn them about the consequences.

The first round of sanctions, officially proclaimed in December 2019, was concentrating only on companies providing vessels for pipeline construction. Their imposition has immediately stopped the construction works which were expected to be completed until summer 2020. Swiss-Dutch company Allsea, which was the main Gazprom's contractor for the laying pipeline, announced the exit of its pipe-laying vessels Pioneering Spirit and Solitaire from the project (Soldatkin et al., 2019). That move could initially kill the hope to complete the pipeline, but Russians have predicted such possible developments and therefore bought earlier other vessels. As a result, the construction works were resumed at the end of January 2021.

In December 2020 US passed the second round of sanctions in the framework of the annual National Defense Authorization Act. This time the menace of facing restrictions on commercial activities was facing not only the companies directly involved in construction works but also those corporate entities engaged in secondary activities like insurance, testing, inspection, etc. services. A new wave of withdrawals from the project started. It was headed by Zurich Insurance Group AG, Danish engineering company Ramboll and Norwegian certifier DNV Holding AS (Vanttinen, 2021).

The first two rounds of sanctions were met negatively by officials of both national and EU supranational levels. Due to their extraterritorial nature, they were seen as US intrusion in internal EU affairs (EURACTIV, 2019). In August 202024 EU member states issued a written complaint to US State Department about the restrictions put on EU companies (Hernandez, 2020). Nevertheless, the lack of tools for reacting on such types of situations was obvious. EU High Representative Josep Borrell even announced a proposal to elaborate the mechanism of the EU's reaction toward extraterritorial sanctions imposed by third parties.

After the start of Joseph Biden's presidential tenure in January 2021, the situation in Washington changed. New US President from Democratic Party-Democrat was less committed to promoting US fossil fuel export. Also, rapprochement with the EU in general and with Germany, in particular, occupied a prominent place in Biden's foreign affairs promises for his term. Continuing hardline behavior on Nord Stream-2 by threatening to sanction EU-based companies would not contribute to the warming of transatlantic relations after the strained period of the Trump administration.

Therefore, to avoid increasing confrontation with the EU, the American position on the pipeline started to soften in February 2021. The vessel Fortuna and its owner, Russian company KVT-Rus, was included additionally in the sanction list in February 2021. However, this extension of sanctions omitted EU companies related to the project (Jirušek \& Dillon, 2021). In May 2021 State Department issued a third round of sanctions which extended the list of Russian entities and ships involved in the construction of Nord Stream. However, at the same time, US lifted the restrictions against Nord Stream-2 AG and its director Mathias Warning motivating this move by national US interests (Shalal et al., 2021). It was widely perceived as US refusal from the hard-line strategy of blocking Nord Stream-2 construction.

\section{Environmental cleavage of political contestation}

The fourth political cleavage which appeared during the deliberations over Nord Stream was about the vision of the future EU energy system in the framework of global planetary effort 
for limiting man-made $\mathrm{CO} 2$ emissions and the role of natural gas in these plans. However, in regard to Nord Stream, EU officials played a minor role in these discussions claiming the lack of formal powers in this area. The basic effort of challenging Nord Stream from an ecological perspective was made by environmental activists, experts and scientist challenging in courts and trying to bring public attention to the correspondence of the Nord Stream-2 pipeline with the general promises about the future development of the energy sector, made on the highest EU political level.

We can distinguish two basic reasons for challenging Nord Stream from the ecological perspective.

The first one is possible harm from pipelines' construction to the Baltic Sea seabed and flora and fauna in affected areas. Already in July 2008, European Parliament supported by a wide majority non-legislative report, prepared by Polish MP Marcin Libicki, questioning the rationale for laying the pipeline on the Baltic seabed due to the presence there of many military mines left there since the times of Second World War (EURACTIV, 2008). The ecological accusations were made later also against the second string of Nord Stream. Berlin-based environmental NGO Nature and Biodiversity Conservation Union (NABU) have calculated that dredging of sea sediments and related to that releasing of bioavailable phosphorus would kill large amount of Baltic sea plants and animals. The construction works also had documented cases of polluting environment, as it was in June 2018 in the Bay of Greifswald in the northeastern part of Germany (Harper, 2018), or killing local plants, as it was in the Russian Kurgalsky nature reserve (Istrate, 2019).

The second line of environmental opposition to the Nord Stream, especially pronounced during the construction of its second string, stressed the project's significance in the context of the policies aimed at the reduction of general European carbon dioxide emissions. Stephan Singer, the senior policy advisor of Climate Action Network (CAN), claimed that in accordance with calculations of his organizations, both strings of Nord Stream would provide more than $10 \%$ of the overall EU CO2 emissions (Singer, 2020).

The representatives of Nord Stream AG tried to justify the rationale of their project with references to the release of greenhouse gases. The company's representatives claimed that technical peculiarities of the gas transportation through the Baltic way provides reducing of carbon emissions by $43 \%$ and $37 \%$ in comparison to Ukrainian and Belorussian corridors, respectively (Pötter, 2021). However, the scenario of full bypassing of existing transit countries as something positive for the climate may be questionable due to the possibility of stopping their transport capacities' exploitation. As Mikhail Korchemkin from East European Gas Analysis suggested in his analysis, the full deposition of Ukrainian pipelines after the full removal of transit may worsen situation with $\mathrm{CO} 2$ emissions in the region: a deficit of gas transport capacities during the peak times coupled with limited transport capacity from western direction might be covered by the increased usage of coal-fired power plants (Korchemkin, 2018: 6-8).

Despite all public doubts about the carbon emissions, the legal basis was not favorable for the real challenging of Gazprom's project from a judicial perspective. All complaints questioning the regulatory framework or methodologies of project's environmental assessments were rejected by the local courts. That was valid for the lawsuits initiated by Environmental Action Germany (Deutsche Umweltshilfe, DUH) (Dziadosz 2020) and journalist Malte Heynen (Schulz 2020) in Germany, of nonprofit organization Clean Earth in Finland and Sweden, and of Greenpease Russia in Russian Federation (Istrate, 2019). 


\section{Conclusions}

The controversial nature of the Nord Stream project exposed different dimensions of political competition, related to the diverging visions of the future of EU energy policy and energy diplomacy. To these battle lines belong international, supranational, transatlantic and environmentalist cleavages.

The analysis of political competition around different aspects of the Nord Stream project implies four basic insights.

First, the discussed issue demonstrated the absence of principal unity among EU member states in regard to both of their materialist economic interests and ideational interpretation of key political developments on the continent.

Second, the appearance of numerous institutional and political obstacles impeding the European Commission's efforts for solving the problem of the Nord Stream project showed the limited powers of the Commission in balancing the interests of different nations under the basic principle of "energy solidarity". The liberal market-oriented spirit of EU legislation complicated the incorporation of any broader geopolitical considerations in decision-making over the pipeline's future by giving the opportunity for project proponents to claim discriminatory treatment.

Third, Brussels' inability to defend the interests of particular post-communist countries in the Nord Stream project issue have additionally underlined the EU's overdependence on the US in geostrategic issues and the problems in realization of idea of "geopolitical Europe" as an independent actor with a coherent strategy on the international level.

But the most important takeaway from our discussion is that the basic design of EU energy policy is based on principles with often contradictory results of practical policy implementation. The materialization of each of the three principles of EU policy in the energy domain (marketization, security, decarbonization) is naturally restrained by the need for taking into account the other two policy goals. In the case of the Nord Stream project that ended by the shaky balance when the proponents of the primacy of each of the principles could be hardly satisfied by the outcome: the construction of the Nord Stream 2 pipeline was not stopped and its role in emitting carbon dioxide was not seriously taken into account, but at the same time, the extension of the jurisdiction of EU energy acquis over the part of the pipeline might substantially harm Gazprom's monopolist position as pipeline's owner.

Future research should put a special emphasis on two basic factors. The first of them is the dualist nature of EU energy diplomacy with its unstable balance between the national interests of EU member states and the supranational manufacturing of common regional position. The second factor is the practical interrelation between different values and desired outcomes in shaping the real-life decision-making processes in the EU political system.

\section{References}

Baltic pipeline under fire despite industry assurances. (2008, July 9). EURACTIV. https://www. euractiv.com/section/energy/news/baltic-pipeline-under-fire-despite-industry-assurances/ Brzozowski, A. (2018, October 25). Nord Stream 2 exposed as Russian weapon against NATO. EURACTIV. https://www.euractiv.com/section/defence-and-security/news/nord-stream-2-exposed-as-russian-weapon-against-nato/

de Jong, M., \& de Graaf, T. (2021). Lost in Regulation: Nord Stream 2 and the Limits of the European Commission's Geo-Economic Power. Journal of European Integration, 43(4), 495-510. https://doi.org/10.1080/07036337.2020.1800680 
Dsiadosz, A. (2020, August 6). Environmental NGO sues to stop Nord Stream 2 over methane leakage concerns. Clean Energy Wire. https://www.cleanenergywire.org/news/environmentalngo-sues-stop-nord-stream-2-over-methane-leakage-concerns

Germany tells US to 'mind its own business' over Nord Stream 2. (2019, December 12). EURACTIV. https://www.euractiv.com/section/energy/news/germany-tells-us-to-mind-its-ownbusiness-over-nord-stream-2/

Gotev, G. (2015, December 4). EU leaders to clash over Nord Stream 2 at summit. EURACTIV. https://www.euractiv.com/section/energy/news/eu-leaders-to-clash-over-nord-stream-2at-summit/

Gotev, G. (2017, March 30). EU offers to negotiate Nord Stream 2 on behalf of members. EURACTIV. https://www.euractiv.com/section/energy/news/eu-offers-to-negotiate-nordstream-2-on-behalf-of-members/

Gotev, G. (2019a, February 8). Nord Stream 2 in dire straits after French U-turn. EURACTIV. $\quad$ https://www.euractiv.com/section/energy/news/nord-stream-2-in-dire-straits-afterfrench-u-turn/

Gotev, G. (2019b, February 8). France "steps on the gas" in eurobudget talks. EURACTIV. https://www.euractiv.com/section/economy-jobs/news/france-steps-on-the-gas-in-eurobudget-talks/

Harper, J. (2018, December 13). Nord Stream 2 pipeline row just got dirty. Deutsche Welle. https://www.dw.com/en/nord-stream-2-pipeline-row-just-got-dirty/a-46697714

Hernandez, A.(2020, August 13). EU countries protest US sanctions in warning to Washington. POLITICO. https://www.politico.eu/article/eu-countries-protest-us-sanctions-say-german-officials/

Istrate, D. (2019, September 18). Pressure builds over environmental impact of Nord Stream 2. Emerging Europe. https://emerging-europe.com/news/pressure-builds-over-environmental-impact-of-nord-stream-2/

Jirušek, M., \& Dillon, R. (2021, March 12). Biden takes a Realpolitik approach on Nord Stream EURACTIV. https://www.euractiv.com/section/global-europe/opinion/biden-takes-a-realpolitik-approach-on-nord-stream-2/

Korchemkin, M. (2018, March 6). The real cost of the Nord Stream 2 for EU and Russia. East European Gas Analysis. https://eegas.com/images/archive/2018-03-06-TallinnKorchemkin.pdf

Lissek, U. (2016). Regulation of Nord Stream 2: Rule of law, equal treatment and due process. A view from the project developer. CEPS Commentary.CEPS. http://aei.pitt.edu/81695/1/ULissikNordstream2.pdf

Nord Stream 2 - Divide et Impera Again? Avoiding a Zero-Sum Game (2017). European Political Strategy Centre. https://www.nabu.de/imperia/md/content/nabude/meeresschutz/180703 papier_epsc_nordstream2.pdf

Poland slaps $€ 6.45$ billion fine on Gazprom over Nord Stream 2 pipeline. (2020, October 7). EURACTIV. https://www.euractiv.com/section/global-europe/news/poland-slaps-e6-45-billion-fine-on-gazprom-over-nord-stream-2-pipelinel

Pötter, B. (2021, March 27). Dispute over Nord stream 2: Climate killer from the pipe. APGPK. https://apgpk.ru/dispute-over-nord-stream-2-climate-killer-from-the/

Rau, Z. \& Kuleba, D.(2021, February 22). Nord Stream 2 has damaged the West enough. Time to put an end to it. POLITICO. https://www.politico.eu/article/nord-stream-2-pipeline-hasdamaged-the-west-enough-time-to-put-an-end-to-it/ 
Riley, A. (2016). Nord Stream 2: A Legal and Policy Analysis. CEPS Special Report No. 151. CEPS. https://www.ceps.eu/ceps-publications/nord-stream-2-legal-and-policy-analysis/

Schulz, F. (2020, March 13). German court rejects last claim against Nord Stream 2. EURACTIV. https://www.euractiv.com/section/energy/news/german-court-rejects-last-claim-against-nordstream-2/

Shalal, A., Gardner, T., \& Holland, S. (2021, May 19). US waives sanctions on Nord Stream 2 as Biden seeks to mend Europe ties. EURACTIV. https://www.reuters.com/business/energy/ us-waive-sanctions-firm-ceo-behind-russias-nord-stream-2-pipeline-source-2021-05-19/

Simon, F. (2019, February 13). EU strikes deal on rules to govern Russia's Nord Stream 2 pipeline. EURACTIV. https://www.euractiv.com/section/energy/news/eu-reaches-deal-on-rules-togovern-russias-nord-stream-2-pipeline/

Singer, S. (2020, September 9). Letter: Nord Stream 2 imperils the EU's green ambitions. Financial Times. https://www.ft.com/content/0d14d650-f055-4f37-adb7-e7384c377151

Soldatkin, V., Grabar, M., Chumakova, N. (2019, December 24). Factbox: How U.S. sanctions could hit Russia's Nord Stream gas project. Reuters. https://www.reuters.com/article/ us-ukraine-russia-gas-factbox-idUSKBN1YSOX5

Sytas, A. (2016, March 16). EU leaders sign letter objecting to Nord Stream-2 gas link. Reuters. https://www.reuters.com/article/uk-eu-energy-nordstream-idUKKCNOWI1 YV

Talus, K. (2020, June 3). Nord Stream 2: New decisions and clear consequences. EURACTIV. https://www.euractiv.com/section/energy/opinion/nord-stream-2-new-decisions-and-clearconsequences/

EU says it does not need Nord Stream 2, but only Germany can block it. (2021, February 24). EURACTIV. https://www.euractiv.com/section/global-europe/news/eu-says-it-does-not-neednord-stream-2-but-only-germany-can-block-it/

Vanttinen, P. (2021, January 18). European companies withdraw from Nord Stream 2 gas pipeline. EURACTIV. https://www.euractiv.com/section/politics/short_news/european-companieswithdraw-from-nord-stream-2-gas-pipelinel

Vicari, M. (2019). The American "New Energy Realism" And The Prospects Of US LNG In The EU. Vocal Europe. Policy Paper. 18 p. https://www.vocaleurope.eu/the-american-new-energyrealism-and-the-prospects-of-us-lng-in-the-eu/

Wehrmann, B., \& Wettengel, J. (2018, August 20). Putin and Merkel meet to find solution on gas pipeline Nord Stream 2. EURACTIV. https://www.euractiv.com/section/energy/news/putin-andmerkel-meet-to-find-solution-on-gas-pipeline-nord-stream-2/ 